\title{
Učinkovitost dekompresijske terapije kralježnice bolesnika s cervikobrahijalnim sindromom
}

1 Lidija Pavlović

2 Dalibor Kiseljak

2 Olivera Petrak

1 Lumbalis centar, Sveti Martin na Muri

2 Zdravstveno veleučilište, Zagreb

\section{Sažetak}

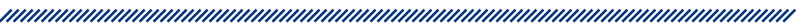

Cervikobrahijalni sindrom uvelike narušava nesmetano obavljanje aktivnosti svakodnevnog života i poslovnih aktivnosti te je predmet brojnih istraživanja. Kompresija neuroloških struktura zbog hernije diska u kralježnici s osjetno-motoričkim deficitom predstavlja indikaciju za operativno liječenje. Posljednjih godina poraslo je zanimanje za trakciju (dekompresiju) kao način liječenja te su razvijene brojne nove metode zasnovane na neurofiziološkim i biokemijskim načelima. Zbog toga se trakcija sve više primjenjuje u liječenju različitih stanja. Dekompresijska terapija kralježnice predstavlja neinvazivan pristup u liječenju cervikobrahijalnog sindroma.

Cilj je ovog istraživanja provjeriti uspješnost dekompresijske terapije kralježnice mjerene kao ishod na specifičnim neurodinamičkim testovima kod bolesnika s cervikobrahijalnim sindromom te utvrditi povezanost sociodemografskih čimbenika s uspješnošću dekompresijske terapije kralježnice kod cervikobrahijalnog sindroma.

$\mathrm{U}$ istraživanju je sudjelovalo 50 sudionika ( $54 \%$ žena) s cervikobrahijalnim sindromom, dobnog raspona od 28 do 68 godina s prosjekom 50. Akutno trajanje simptoma zabilježeno je kod $62 \%$ bolesnika, a kronično kod
$38 \%$. Frekvencija dolazaka na terapiju kreće se od 3 do 8 , s dominantnom vrijednošću 4 . Za potrebe istraživanja primjenjivala su se tri specifična testa: Slump test, Spurlingov test i test cervikalne distrakcije.

Osobe s cervikobrahijalnim sindromom nakon provedene dekompresijske terapije kralježnice značajno se razlikuju u ishodu na Slump testu, Spurlingovu testu i testu cervikalne distrakcije u odnosu na stanje prije terapije: nakon terapije ima značajno više osoba koje uspješno prolaze navedene testove. Od promatranih sociodemografskih obilježja, značajna se pokazala dob sudionika: sudionici koji uspješno rješavaju Slump test i Spurlingov test nakon terapije znatno su mlađi od neuspješnih. Kronični bolesnici nakon terapije postižu znatno slabiji ishod na sva tri testa u odnosu na akutne bolesnike, a te se dvije skupine ujedno razlikuju i po dobi: kronični bolesnici znatno su stariji, dok po broju dolazaka na terapije nije nađena značajna razlika. U regresijskoj analizi trajanje oboljenja pokazalo se kao značajan prediktor, za razliku od dobi, koja nije značajna. Spol, tjelesna težina te broj dolazaka na terapije nisu povezani s učinkom na testovima.

Ključne riječi: cervikobrahijalni sindrom, dekompresijska terapija, trakcija, neurodinamički test

Datum primitka: 13.07.2015.

Datum prihvaćanja: 30.10.2015.

Adresa za dopisivanje:

Dalibor Kiseljak, dipl. physioth., mag. educ. art.

Zdravstveno veleučilište Zagreb

Mlinarska cesta 38

Tel. 00385915495736

E-pošta: dalibor.kiseljak@zvu.hr 


\section{Uvod}

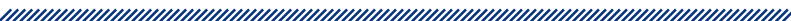

Moderan, sjedilački i užurban način života dovodi do činjenice da u današnje vrijeme svaka druga osoba ima problema s kralježnicom. Višesatni rad za računalom, dugotrajna vožnja automobilom i tjelesna neaktivnost samo su neki od čimbenika koji potiču mehaničke poremećaje struktura vratne kralježnice te rezultiraju pojavom bolova. Tijekom zauzimanja neadekvatnog položaja glava je nagnuta naprijed, što napreže ili opterećuje stražnju stranu vrata gdje se nalaze mišići, tetive, zglobne sveze, mali zglobovi i kralježnični diskovi. $U$ vratnoj su kralježnici česte neugodne bolne epizode koje mogu biti uzrokovane iznenadnim pokretom, ali i općenito lošim držanjem tijela ${ }^{1}$.

Iza bolnih senzacija u vratu najčešće se kriju degenerativne promjene. One su ujedno najčešći uzročnik cervikobrahijalnog sindroma, a započinju vrlo rano, već oko tridesete godine života ${ }^{2}$. Pretežno se javljaju na mjestima gdje je kralježnica najopterećenija, odnosno na mjestima gdje dolazi do prijelaza segmenta koji je dobro gibljiv u segment koji je slabije gibljiv (prijelaz cervikalnog u torakalni dio kralježnice).

Patološko-anatomski supstrat pretežno je lociran na srednjem i donjem dijelu vratne kralježnice ${ }^{3}$. Cervikobrahijalni splet prolazi na svojem putu do grananja u rukama kroz više uskih anatomskih prolaza u kojima može biti iritiran, osobito nakon involucijskih promjena mišića odgovornih za održavanje tih prolaza te uslijed određenih položaja (tijekom rada, spavanja).

Glavna je tegoba bol radikularnog tipa koja se, ovisno o distribuciji korijena, širi u cijelu ruku. Bol može biti izolirani znak ili se javlja s parestezijama u prstima šaka4.

U dijagnostici središnje mjesto zauzimaju anamneza i fizikalni pregled, koji se prema potrebi mogu nadopuniti radiološkim pretragama, elektromioneurografijom, kompjutoriziranom tomografijom, magnetskom rezonancijom, ultrazvukom i laboratorijskim pretragama ${ }^{5}$. Ako se tijekom pregleda posumnja na afekciju korijena spinalnog živca (smanjenje osjeta ili radikularno širenje boli), fizikalni se pregled nadopunjava i neurološkim pregledom tijekom kojeg se ispituju osjet, refleksi, mišićna snaga i trofičke promjene muskulature ${ }^{6}$.

Ako je riječ o protruziji intervertebralnog diska, indicirana je trakcija kojom se postiže proširenje intervertebralnih prostora, smanjenje iritacije spinalnih korijena, uklanja bol i ostale simptome te se sprječava razvoj adhezija. Trakcija se provodi kontinuirano ili intermitentno, a treba djelovati u smjeru uzdužne osi kralježnice, što se postiže namještanjem bolesnika u položaj ispružene vratne lordoze ${ }^{4}$. Trakcija je pasivna terapijska metoda koja se sastoji od istezanja određenih dijelova tijela primjenom mehaničke sile ${ }^{7}$. Drugi su nazivi za trakciju ekstenzija, distrakcija i dekompresijska terapija.

Trakcija elongira kralježnicu, mišiće i ligamente, povećava međukralježnični prostor, zglobne površine međukralježničnih zglobova i međukralježnične otvore. Te promjene dovode do relaksacije paravertebralnih mišića, do smanjenja izbočenja herniranog diska i smanjenja pritiska na korijen spinalnog živca u području međukralježničnog otvora ${ }^{8}$.

Rezultati trakcije ovise o sili i o smjeru djelovanja sile, duljini primjene, anatomskim obilježjima bolesnika te 0 površini na kojoj leži ${ }^{8}$. Trajanje i smjer primjene sila ovise o: patologiji (hernija diska, artroza, mišićni grč), dijelu kralježnice u kojem je patološki proces prisutan, težini i položaju dijela tijela koji se liječi, vrsti trakcije (kontinuirana, intermitentna), pacijentovu stanju (spol, dob, opće zdravstveno stanje) i pacijentovoj podnošljivosti.

Dekompresija uzrokuje negativan pritisak unutar diska koji stvara osmotski pad tlaka, uslijed čega dolazi do pritjecanja nutrijenata i vode u oštećeni disk, što omogućava njegovo zacjeljivanje i vraćanje odgovarajuće funkcije. Time se postiže i pojačava prirodni proces zacjeljivanja diska, a kako disk zacjeljuje, povlače se simptomi bol i disfunkcija jer prestaje mehanički pritisak na živce i korijene živaca unutar spinalnog kanala.

Trakcija vratne kralježnice primjenjuje se kod hernije diska i disfunkcije mekog tkiva. Provodi se kod subakutne i kronične križobolje, cervikalnog sindroma, cervikobrahijalnog sindroma, protruzije interverterbalnog diska, priklještenja živčanog korijena, hipomobilnosti zglobova kralježaka, subakutne ili kronične neinfektivne upale zglobova ili grča paraspinalnih mišića.

Prije primjene trakcije potrebno je izvesti trakcijski test. Ako se testom utvrdi da se bol trakcijom smanjuje, postupak se nastavlja.

Prilikom provođenja trakcije potrebno je odrediti položaj koji mora biti relaksirajući. Ako paravertebralni mišići nisu relaksirani, prije trakcije treba primijeniti druge procedure (topli oblog, infracrvenu lampu, ultrazvuk, krioterapiju) kojima će se olabaviti mišići. Trakcija vratne kralježnice izvodi se u ležećem ili sjedećem položaju. Položaj 30 stupnjeva inklinacije najpovoljniji je za šire- 
nje intervertebralnih otvora i fasetnu disfunkciju. Tada je čahura intervertebralnog zgloba u najrelaksiranijem položaju, a fasete su cervikalne kralježnice pokretne. Za svakog se pacijenta mora odrediti veličina inklinacije. Za segment C1 - C2 inklinacija iznosi od 0 do 5 stupnjeva, a za donje vratne kralješke ( $C 5-\mathrm{C} 7$ ) iznosi od 25 do 30 stupnjeva. U tim su položajima ligamenti i zglobne čahure intervertebralnih zglobova u relaksiranom položaju.

Uređaj kojim se izvodi mehanička trakcija sastoji se od ležaja i omče u koju se smješta bolesnikova glava te se izvodi trakcija u položaju ležeći na leđima (slika 1).

Sila koja se primjenjuje za gornji dio vratne kralježnice pri trakciji iznosi od 5 do $8 \mathrm{~kg}$, a za srednji i donji dio od 15 do $25 \mathrm{~kg}$. Liječenje traje relativno kratko, obično od 5 do 10 minuta za disfunkciju diska i od 10 do 15 minuta za druga stanja.

Trakcija se ne primjenjuje kod osoba s teškim kardiovaskularnim i respiratornim bolestima, aortalnom ili ilijačnom aneurizmom, abdominalnom hernijom, teškom osteoporozom, inflamatornim spondiloartritisom, malignitetom u području kralježnice ili mišićnom insuficijencijom te kod pogoršanja simptoma nakon primjene trakcije s izraženijim bolovima ili periferizacijom simpto$\mathrm{ma}^{9}$. Trakcija je općenito kontraindicirana kod bolesnika s lokalnom i sistemskom bolešću zglobova, akutnim ozljedama, hipermobilnošću, vaskularnim promjenama i temporomandibularnom disfunkcijom? ${ }^{7}$.

S obzirom na to da je ova vrsta terapije relativno rijetka u Hrvatskoj, a istraživanja nisu provođena, smatrali smo shodnim provjeriti djelotvornost navedene terapije u našim uvjetima pa je cilj ovog istraživanja provjeriti

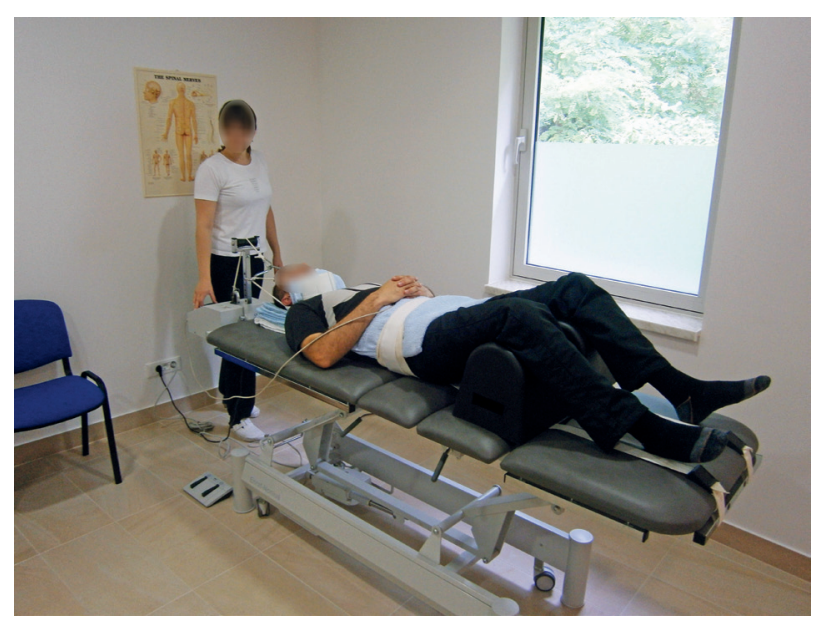

Slika 1. Dekompresijska terapija cervikalne kralježnice uspješnost dekompresijske terapije kralježnice mjerenu kao ishod na tri različita testa (test cervikalne distrakcije, Spurlingov test, Slump test) kod bolesnika s cervikobrahijalnim sindromom te utvrditi povezanost sociodemografskih čimbenika s uspješnošću dekompresijske terapije kralježnice kod cervikobrahijalnog sindroma.

\section{Metode}

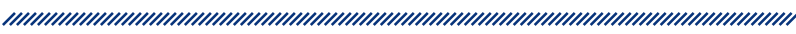

Istraživanje je provedeno u Lumbalis centru u LifeClass termama Sveti Martin tijekom 2013. godine na uzorku od 50 sudionika s cervikobrahijalnim sindromom. Prosječna dob sudionika iznosila je 50 godina (28 do 68). U istraživanju su poštivane sve etičke smjernice: sudjelovanje $u$ istraživanju bilo je dobrovoljno, a sudionici su bili upoznati s postupkom i primjenom rezultata u istraživačke svrhe.

Kao indikator djelotvornosti dekompresijske terapije primijenjena su tri specifična neurodinamička testa: Slump test, test cervikalne distrakcije i Spurlingov test. Maitlandov Slump test široko je primijenjen test neuralne tenzije ${ }^{10}$, dok se test cervikalne distrakcije i Spurlingov test zbog svoje zadovoljavajuće dijagnostičke točnosti ${ }^{11}$ ubrajaju u najčešće upotrebljavane provokacijske testove namijenjene kliničkoj procjeni područja vrata i cervikalne kralježnice kod radikulopatija ${ }^{12}$.

Slump test procjenjuje pridonosi li hernija diska, neuronska napetost ili izmijenjena neurodinamika pogoršanju simptoma. Test se izvodi tako da ispitanik sjedi u pogrbljenom položaju s rukama iza leđa. Ispitivač pozicionira ispitanika u položaj flektirane kralježnice, posebno cervikalnog dijela. Ispitivač stavlja ruke na tjeme ispitanika, koji potom izvodi ekstenziju koljena i dorzalnu fleksiju stopala. Na kraju se ispitanik vraća u neutralan početni položaj. Test je pozitivan ako se simptomi intenziviraju u flektiranom položaju, a smanjuju se u neutralnom položaju ${ }^{13,14}$.

Spurlingov je test medicinski postupak koji se primjenjuje za ispitivanje korijena živaca. Test se izvodi u sjedećem položaju. Ispitanik izvodi laterofleksiju glave u stranu koja nije simptomatski zahvaćena. Aplicira se aksijalna kompresija (lagani pritisak rukom). Nakon toga se postupak ponavlja i na suprotnoj strani. Test se smatra pozitivnim ako tijekom njegova izvođenja dolazi do intenziviranja simptoma ${ }^{15}$, odnosno ako bol iradira prema ruci strane na koju je glava flektirana ${ }^{12}$. Spurlingov test pokazuje točnost u više od $90 \%$ slučajeva prolapsa cervikalnog diska ${ }^{16}$. 
Test cervikalne distrakcije izvodi se u supiniranom položaju. Ispitivač pozicionira obje svoje ruke iza glave ispitanika, u području mastoidnih nastavaka, te se glava lagano potiskuje prema tijelu. Test je pozitivan ako se potiskivanjem glave prema tijelu simptomi intenziviraju, a trakcijom odnosno izvlačenjem smanjuju ${ }^{12,15}$.

Specifični su testovi provođeni prije i poslije dekompresijske terapije kralježnice. Proces dekompresijske te-

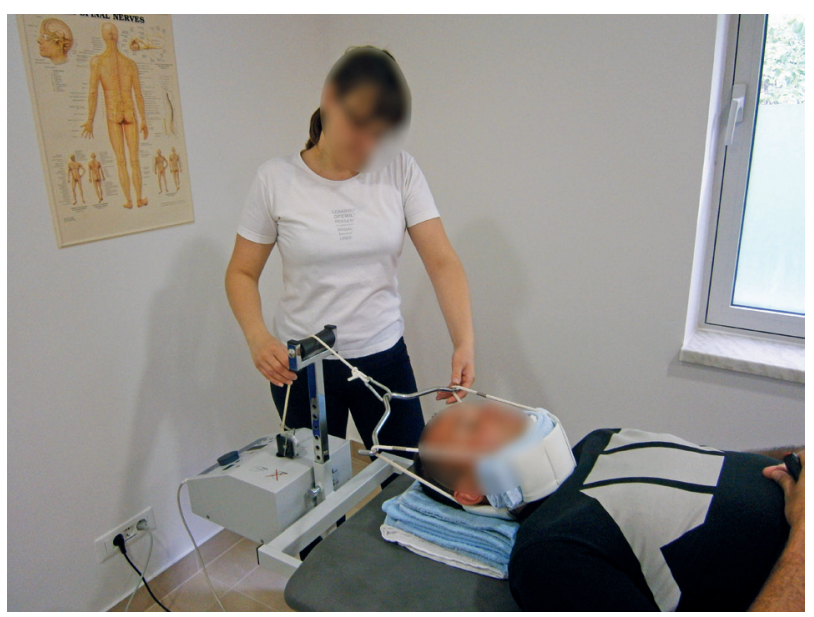

Slika 2. Intermitentna trakcija na uređaju Eltrac rapije kralježnice obuhvaća zagrijavanje infracrvenom lampom u trajanju od 10 minuta, intermitentnu trakciju na uređaju Eltrac u trajanju od 15 minuta (slika 2), elektroterapiju u trajanju od 30 minuta i magnetoterapiju u trajanju od 15 minuta. Frekvencija dolazaka sudionika na dekompresijsku terapiju kralježnice kreće se od tri do maksimalno osam dolazaka, s prosječnom vrijednošću 4,6 (dominantna je vrijednost četiri dolaska).

\section{Rezultati}

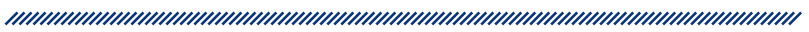

Zanimala nas je uspješnost dekompresijske terapije kralježnice kod bolesnika s cervikobrahijalnim sindromom u vidu ishoda na tri različita testa: Slump test, Spurlingov test te test cervikalne distrakcije. $U$ istraživanju je sudjelovalo 50 sudionika dobnog raspona od 28 do 68 godina s prosjekom $50 \pm 11$,9 godina. Žena je 27 (54\%), a 23 su osobe ( $46 \%$ ) muškog spola. Prosječna tjelesna težina sudionika iznosi $78 \mathrm{~kg}$, s rasponom od 58 do 100 kg. Akutno trajanje simptoma zabilježeno je kod 31 osobe (62\%), a kronično trajanje kod 19 (38\%). Kriterij akutno/kronično odnosi se na trajanje oboljenja ${ }^{17}$. Na slici 3 prikazani su rezultati testiranja prije i nakon

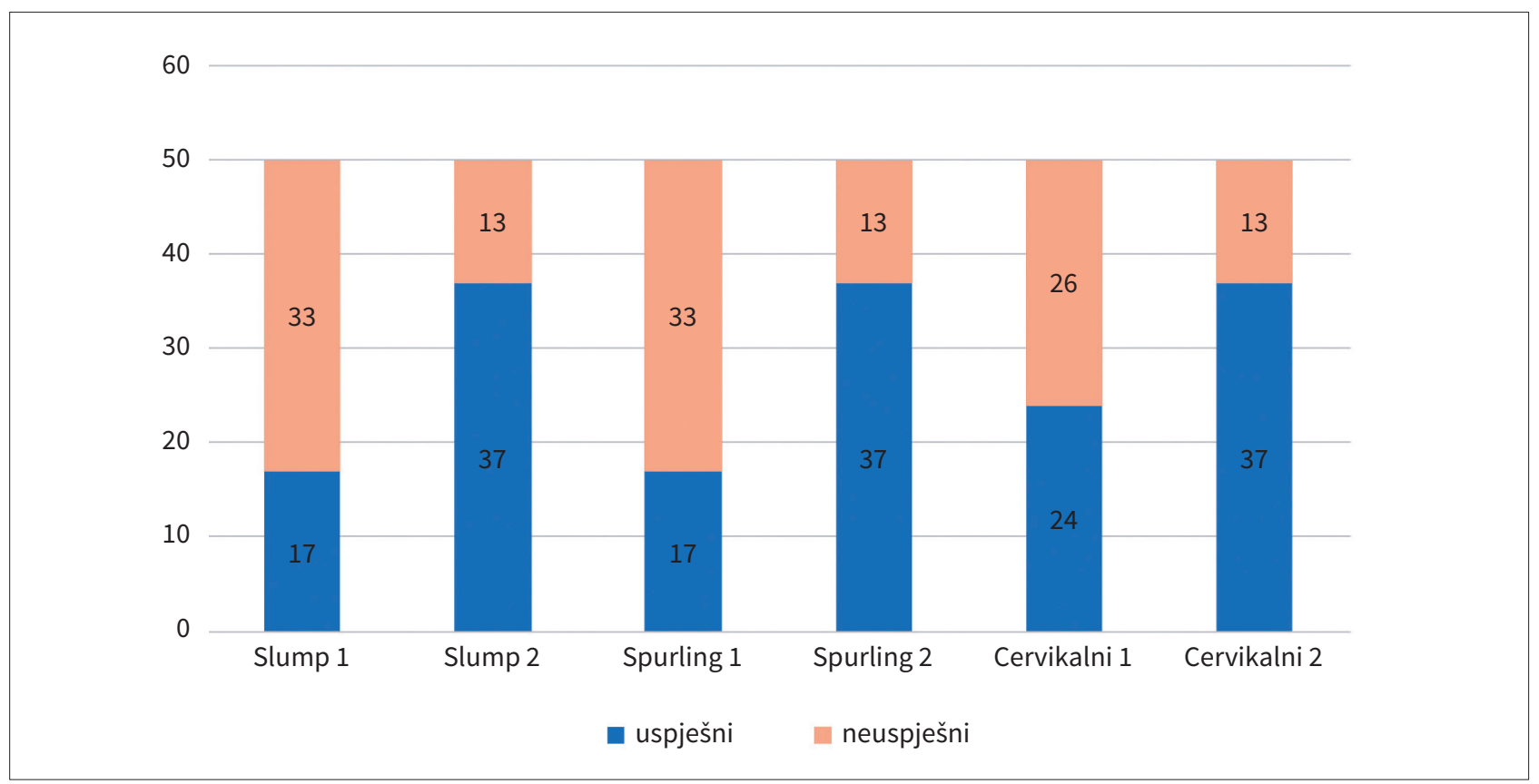

Slika 3. Broj bolesnika s cervikobrahijalnim sindromom s neuspješnim i uspješnim ishodom na Slump testu, Spurlingovu i testu cervikalne distrakcije prije (1) i nakon (2) provedene dekompresijske terapije kralježnice $(\mathbf{N}=50)$ 
provedene dekompresijske terapije kralježnice. Pozitivan nalaz označava nepovoljan, neuspješan ishod na testu, dok je negativan nalaz uspješan.

Vidljivo je da je nakon terapije povećan broj bolesnika koji uspješno izvode testove, a McNemarov test pokazao je da je razlika u rezultatima na promatranim testovima prije i nakon dekompresijske terapije kralježnice statistički značajna u smjeru boljih nalaza nakon terapije: za Slump test $p=0,000$; za Spurlingov test $p=0,002$; za test cervikalne distrakcije $p=0,001$.

Dodatno nas je zanimalo i kakav je odnos sociodemografskih čimbenika i napretka bolesnika s cervikobrahijalnim sindromom na primijenjenim testovima. Levenov test homogenosti varijance provjeren je prije svakog t-testa te je u svim usporedbama pokazao da su skupine homogene. Muški i ženski ispitanici ne razlikuju se značajno po dobi ( $t=0,33$; $d f=48 ; p=0,743$ ), kao ni po broju dolazaka na terapiju $(\mathrm{t}=1,001 ; \mathrm{df}=48$; $\mathrm{p}=0,322$ ). Ishod na Slump testu nakon dekompresijske terapije kralježnice ne razlikuje se statistički značajno s obzirom na spol: $\chi^{2}=0,435 ; \mathrm{df}=1 ; p=0,509$. Ni za Spurlingov test nije nađena bitna razlika po spolu: $\chi^{2}=0,435$; $\mathrm{df}=1 ; \mathrm{p}=0,509$, a identičan je rezultat dobiven $\mathrm{i}$ za test cervikalne distrakcije.

Dob se pokazala relevantnim čimbenikom: nakon dekompresijske terapije kralježnice sudionici s pozitivnim ishodom na Slump testu i na Spurlingovu testu statistički su znatno stariji od sudionika s negativnim ishodom (tablica 1): prosječna dob bolesnika s pozitivnim nalazom iznosi 55,7, dok su bolesnici koji su uspješno obavili oba testa (negativan nalaz) u prosjeku stari 47,7 godina. I na testu cervikalne distrakcije nakon terapije uspješniji su mlađi bolesnici, no razlika u dobi nije statistički značajna.

Tjelesna težina ne razlikuje se kod bolesnika s pozitivnim i s negativnim ishodom nakon dekompresijske terapije kralježnice ni na Slump testu, kao ni na Spurlingovu testu: $\mathrm{t}=0,094 ; \mathrm{df}=48 ; \mathrm{p}=0,926$, a također ni na testu cervikalne distrakcije: $t=0,338 ; d f=48 ; p=0,737$.
Razlika u ishodu na testovima nakon dekompresijske terapije kralježnice identična je za sva tri testa te je statistički značajna s obzirom na trajanje simptoma kod bolesnika s cervikobrahijalnim sindromom: kronični bolesnici s cervikobrahijalnim sindromom imaju znatno lošiji ishod nakon terapije; $\chi^{2}=11,3 ; \mathrm{df}=1 ; \mathrm{p}=0,001$. Bolesnici s kroničnim oboljenjem ujedno su i znatno stariji: $t=5,4 ; d f=48 ; p=0,000$. Kronični bolesnici $u$ prosjeku imaju 59 godina, za razliku od akutno oboljelih prosječne dobi 44 godine. Kronični i akutni bolesnici međusobno se znatno ne razlikuju po prosječnom broju dolazaka na terapiju: $\mathrm{t}=0,537 ; \mathrm{df}=48 ; \mathrm{p}=0,594$.

Skupine bolesnika koji jesu odnosno nisu uspješni u primijenjenim testovima nakon terapije ne razlikuju se znatno po broju dolazaka na terapije (Slump test i Spurlingov test: $t=1,307 ; d f=48 ; p=0,197$; test cervikalne distrakcije: $t=0,291 ; d f=48 ; p=0,773$ ).

S obzirom na to da se sudionici znatno razlikuju i po dobi i po trajanju oboljenja u ishodu na Slump testu i Spurlingovu testu, s pomoću jednostavne regresijske analize željeli smo provjeriti njihov međusobni odnos. Stoga smo kao prediktore uključili dob i trajanje oboljenja, dok su kriteriji bili ishodi na ova dva testa nakon

Tablica 2. Regresijska analiza za kriterijsku varijablu ishoda na Slump testu i Spurlingovom testu nakon provedene dekompresijske terapije kralježnice kod pacijenata s cervikobrahijalnim sindromom $(\mathbf{N}=\mathbf{5 0})$

\begin{tabular}{|c|c|c|}
\hline Prediktori & beta & $\mathrm{t}$ \\
\hline Dob & 0,011 & 0,069 \\
\hline Trajanje oboljenja & 0,468 & $2,881^{\star \star}$ \\
\hline \multicolumn{3}{|l|}{$R=0,475$} \\
\hline \multicolumn{3}{|l|}{ Korigirani R2 = 0,193 } \\
\hline \multicolumn{3}{|l|}{$F(2,47)=6,862^{\star \star}$} \\
\hline $\begin{array}{l}\text { ** Značajnost na razini od } 0,01 \\
\text { * Značajnost na razini od } 0,05\end{array}$ & & \\
\hline
\end{tabular}

Tablica 1. Aritmetičke sredine dobi i t-testovi između uspješnih i neuspješnih bolesnika na Slump testu, Spurlingovom i testu cervikalne distrakcije nakon provedene dekompresijske terapije kralježnice kod pacijenata s cervikobrahijalnim sindromom $(\mathbf{N}=50)$

\begin{tabular}{|c|c|c|c|c|c|}
\hline Test & ishod & dob & $\mathrm{t}$ & df & $\mathrm{p}$ \\
\hline \multirow{2}{*}{ Slump i Spurlingov } & uspješni & 47,7 & \multirow{2}{*}{2,17} & \multirow{2}{*}{48} & \multirow{2}{*}{0,035} \\
\hline & neuspješni & 55,7 & & & \\
\hline \multirow{2}{*}{ Cervikalna distrakcija } & uspješni & 48,6 & \multirow{2}{*}{1,12} & \multirow{2}{*}{48} & \multirow{2}{*}{0,268} \\
\hline & neuspješni & 52,9 & & & \\
\hline
\end{tabular}


terapije. Prediktori međusobno značajno umjereno koreliraju (point-biserijalni $r=0,612$ ), a njihove korelacije $s$ ishodima na testovima su također značajne i umjerene (point-biserijalni $r=0,475$ između trajanja oboljenja i testova, odnosno $r=0,297$ između dobi i testova). $\mathrm{Iz}$ tablice 2 vidljivo je da je trajanje oboljenja značajan prediktor za ishod na Slump testu i Spurlingovu testu nakon provedene terapije te taj prediktor objašnjava skromnih $19 \%$ varijance ishoda na testovima. Kronični bolesnici postižu znatno slabije ishode na Slump testu i Spurlingovu testu nakon terapije. Dob se nije pokazala kao značajan prediktor.

\section{Diskusija}

Kao kriterij uspješnosti dekompresijske terapije kralježnice uzeli smo ishode na tri neurodinamička testa: Slump test, Spurlingov test $\mathrm{i}$ test cervikalne distrakcije. Pozitivan nalaz na testu znači da je stanje bolesnika nezadovoljavajuće, dok negativan nalaz znači da je došlo do uklanjanja simptoma. Brojni autori navode prikladnost navedenih testova u svrhu postavljanja dijagnoze cervikalne radikulopatije ${ }^{10-13,16,18,19}$

Nakon provedene terapije vidljiv je povećan broj sudionika koji mogu ispuniti zahtjeve navedenih testova u odnosu na situaciju prije terapije, a ustanovljene su razlike i statistički značajne za sva tri testa. S obzirom na to da je primijenjeni nacrt predeksperimentalnog tipa, ne možemo govoriti o terapiji kao uzroku poboljšanja stanja bolesnika, ali je povezanost terapije i stanja bolesnika neupitna. Nalazi su u skladu s očekivanjima, jer su brojna istraživanja već dokazala djelotvornost dekompresijske terapije kod bolesnika s cervikobrahijalnim sindromom ${ }^{20-25}$, iako uz različite procjene i/ili intervencije. $U$ istraživanjima novijeg datuma u svrhu procjene primjenjuju se neck disability index (NDI) i vizualno analogna skala (VAS), kao i verbal rating scale (VRS), a terapija varira između kontinuirane i intermitentne. To ukazuje na brojnost kriterija koji reflektiraju djelotvornost dekompresijske terapije.

U svakom testu $26 \%$ bolesnika ni nakon terapije nije bilo uspješno. Razlog za to možemo naći u nedovoljnom broju provedenih terapija, jer je čak 18 bolesnika (36 \%) na terapiju došlo samo tri puta, što uglavnom nije dovoljno da bi se stanje stabiliziralo, pogotovo ako je riječ o kroničnom oštećenju. lako su dobili drugačiju uputu, većina bolesnika prekida terapiju prije nego što je provedena do kraja. Naime bolesnici sami plaćaju terapiju, što predstavlja znatan financijski izdatak, a također razlog može biti i nedostatak vremena. Nerijetko bolesnici procjenjuju da je došlo do dovoljnog poboljšanja ako je bol smanjena na podnošljivu razinu, odnosno ako je potpuno nestala, dok im drugi kriteriji, npr. pokretljivost, nisu toliko važni.

Radi utvrđivanja značajnosti razlike u uspješnosti terapije po spolu prethodno smo provjerili razlikuju li se muškarci i žene značajno po dobi ili po broju dolazaka na terapiju, kako nam ti podaci ne bi interferirali sa spolom. Pokazalo se da razlike nisu značajne, ali ni razlika po spolu nije se pokazala statistički značajnom u ishodu nakon terapije ni na jednom navedenom testu. Također, udio muškog i ženskog spola u uzorku nije značajno različit. lako, prema Krapcu, jedan je od najčešćih bolnih sindroma kralježnice kod žena cervikobrahijalni sindrom u kojem se zbog promjena oblika i funkcije u donjoj trećini vratne kralježnice (oštećenje intervertebralnog diska) bolovi iz vrata šire u ramena, nadlaktice i šake. Bolni su sindromi učestaliji kod žena starije životne dobi ${ }^{26}$. No što se promatranih testova tiče, jednako ih uspješno mogu obavljati pojedinci oba spola jer tjelesna snaga ne igra važnu ulogu u njihovu izvođenju pa to može objasniti nepostojanje razlike.

Za razliku od spola, dob se pokazala naizgled relevantnim čimbenikom; skupina koja ima negativan nalaz na Slump testu i Spurlingovu testu znatno je mlađa, i to za punih osam godina, od skupine $s$ pozitivnim nalazom $(47,7$ godina u odnosu na 55,7$)$. Na testu cervikalne distrakcije nije nađena značajna razlika s obzirom na dob. Takav je nalaz i očekivan jer je u starijoj dobi češći problem kronične prirode i uznapredovale su degenerativne promjene interverteberalnog diska. Nakon tridesete godine života anulus fibrosus intervertebralnog diska počinje gubiti svoju rezistenciju te degenerira ${ }^{26}$. Kasnije će u prikazu rezultata regresijske analize biti dodatno pojašnjen odnos dobi i ishoda na testovima.

Nema razlike u tjelesnoj težini kod sudionika s pozitivnim i negativnim ishodom na testovima nakon terapije. lako povećana tjelesna težina može ometati obavljanje aktivnosti svakodnevnog života, u ovom slučaju ipak nije igrala nikakvu ulogu, jer se navedeni testovi mogu uspješno obaviti i s povećanom tjelesnom težinom, barem do određene mjere. Kronični bolesnici s cervikobrahijalnim sindromom imaju značajno lošiji ishod na sva tri testa u odnosu na akutne bolesnike. Nalaz je u skladu s očekivanjima, jer akutna stanja nastaju brzo i 
relativno su kratkog trajanja te ih je, ako se na vrijeme dijagnosticiraju, lakše liječiti. Kronična se stanja obično razvijaju sporije, traju kontinuirano duže ili se ponavljaju kroz duže vremensko razdoblje, a zbog svoje prirode utječu na kvalitetu života. Kronična stanja iziskuju mnogo duži vremenski rok kako bi došlo do uklanjanja simptomatskih smetnji.

Po broju dolazaka na terapiju nije utvrđena značajna razlika između osoba s pozitivnim i negativnim nalazom u testovima nakon provedene terapije. Broj dolazaka kreće se između 3 i 8 s dominantnom vrijednošću 4, što u većini slučajeva nije dovoljno za potpuno saniranje stanja. Moguće objašnjenje leži u tome da kriterij prekida terapije nije, nažalost, zadovoljavajuće stanje bolesnika, već njegova ekonomska situacija, raspoloživo vrijeme te motiviranost i angažiranost.

Dvije skupine različite po trajanju oboljenja (akutno/ kronično) ne razlikuju se značajno po broju dolazaka na terapiju, ali se značajno razlikuju po dobi i po ishodima na testovima (15 su godina stariji bolesnici s pozitivnim nalazom na testovima) pa se postavlja pitanje što predstavlja izvorni odnos s ishodima na testu, a što je posljedica spuriozne korelacije. S obzirom na to da dob i trajanje oboljenja međusobno značajno umjereno koreliraju, a njihove su korelacije $s$ ishodima na testovima također značajne i umjerene, proveli smo regresijsku analizu s prediktorima dob sudionika i trajanje oboljenja, dok je kriterij bio ishod na Slump testu i Spurlingovu testu nakon provedene dekompresijske terapije kralježnice. Jedino se trajanje oboljenja pokazalo značajnim prediktorom te objašnjava $19 \%$ varijance ishoda na testovima.

Svakako je očekivana povezanost kronične pojave simptoma s većom kronološkom dobi. Nalaz se poklapa s podatkom da se dobna granica pojave cervikobrahijalnog sindroma spušta sve niže, pa tako i u ovom istraživanju nalazimo čak $20 \%$ sudionika u dobi do 35 godina. lako je tijekom adolescentne i mlađe životne dobi intervertebralni disk posve elastičan i funkciona$\operatorname{lan}^{27}$, sjedilački, užurbani život u kombinaciji s fizičkom neaktivnošću sve više snižava dobnu granicu pojavnosti ovih teškoća. Učestalost cervikobrahijalnog sindroma u SAD-u iznosi $13 \%$ muškaraca i 5 \% žena u četvrtom desetljeću života, dok je u osmom desetljeću života učestalost veća od $95 \%$ u oba spola ${ }^{28}$.

U rezultatima možemo primijetiti izrazito poklapanje rezultata na Slump testu i Spurlingovu testu, stoga je u budućim istraživanjima možda dovoljno primjenjivati samo jedan od njih, kako bi vrijeme testiranja bilo kraće. Spurlingov test jednostavniji je za provođenje, primjena kraće traje, fokusiran je na gornje segmente te je široko prihvaćen kao metoda za dokazivanje cervikalne radikulopatije ${ }^{16}$. Slump test ima više koraka u provedbi, prisutne su sličnosti s drugim testovima, a širina mogućnosti interpretacije čini ga kompliciranijim od većine ortopedskih i neuroloških testova. Međutim, faktori koji ga čine kompliciranijim također ga čine svestranim, učinkovitim i pouzdanim ${ }^{19}$. S obzirom na kliničke odnosno istraživačke potrebe i uvjete moguće je odabrati jedan od navedenih testova. Za razliku od njih, test cervikalne distrakcije u inicijalnom je mjerenju nešto slabije dijagnosticirao poteškoće bolesnika: u odnosu na druga dva testa, ovdje je veći broj bolesnika bio uspješan prije terapije. Stoga bi u situaciji vremenske ograničenosti preporučili uporabu Spurlingova testa u dijagnostičke svrhe, dok bi za dobivanje šire slike o poteškoćama bolesnika prvi izbor bio Slump test.

Primijenjeni testovi imaju ishode na razini nominalne skale (pozitivan/negativan), što je prilično robusna mjera koja ne zahvaća suptilne promjene u stanju i funkciji bolesnika. S druge strane, ovi su testovi i vremenski i financijski vrlo ekonomični, a njihovi se nalazi u izrazito visokom postotku poklapaju s nalazima znatno skupljih pretraga (npr. magnetska rezonancija) ${ }^{11,16,29,30}$ ili onih koje uključuju zračenje bolesnika (npr. radiografija, kompjuterizirana tomografija). Uzimajući u obzir te i ostale rizike, kao i skupoću pretraga, smatramo da costbenefit analiza opravdava primjenu specifičnih neurodinamičkih testova. Također, prema Wainneru i Gillu, kompjuterizirana tomografija, magnetska rezonancija i radiografija ukazuju na patoanatomsku dijagnozu kod i do $75 \%$ asimptomatskih slučajeva, ovisno o dobi ${ }^{31}$. Uvid u promjene na koštanim strukturama i diskovima nije garancija da su navedene strukture izvor bolesnikovih radikularnih znakova i simptoma, s obzirom na to da u funkciji vertebralnih dinamičkih segmenata sudjeluju i mnoga druga tkiva.

\section{Zaključci}

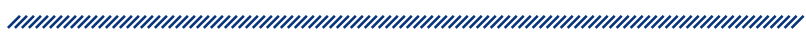

Osobe s cervikobrahijalnim sindromom nakon provedene dekompresijske terapije kralježnice značajno se razlikuju u ishodu na Slump testu, Spurlingovu testu i testu cervikalne distrakcije u odnosu na stanje prije terapije. Nakon terapije ima znatno više ispitanika koji uspješno prolaze navedene testove. 
Nije utvrđena statistički značajna razlika ni po spolu ni po tjelesnoj težini, kao ni po broju dolazaka na terapije $\mathrm{u}$ ishodu na promatranim testovima nakon provedene terapije, dok su sudionici koji uspješno rješavaju Slump test i Spurlingov test nakon terapije znatno mlađi od onih koji nisu uspješni. Kod testa cervikalne distrakcije nije nađena značajna razlika po dobi. Kronični bolesnici postižu u značajno većoj mjeri slabiji ishod na sva tri testa nakon terapije u odnosu na bolesnike koji su u akutnom stanju, a te se dvije skupine ujedno razlikuju i po dobi: kronični bolesnici znatno su stariji; dok po broju dolazaka na terapije nije nađena znatna razlika.

\section{Literatura}

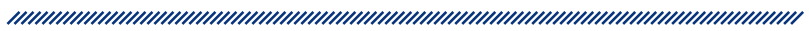

1. McCormack BM, Weinstein PR. Cervical spondylosis. An update. Western Journal of Medicine. 1996;165(1-2):43-51.

2. Kolak A, Kolak M. Klinička medicina. Naklada Mosta; 2004. 197-225.

3. Jajić I, Jajić Z. Reumatologija u praksi. Zagreb: KB Sestre milosrdnice; 1999. 125-131.

4. Jajić I. Specijalna fizikalna medicina. Zagreb: Školska knjiga; 1991. 24-31.

5. Baričić M. Degenerativne bolesti kralježnice. Klinika za ortopediju Lovran; 2009.

6. Dvorák J. Epidemiology, physical examination, and neurodiagnostics. Spine. 1998;23(24):2663-73.

7. Jajić I., Jajić Z. i sur. Fizikalna i rehabilitacijska medicina. Zagreb: Medicinska naklada; 2008. 290-330.Weisberg J, Hecox B, Mekreteab TA. Spinal traction. Norwalk, Connecticut: Appleton \& Lange; 1994. 349-417.

8. Wong AM, Leong CP, Chen CM. The traction angle and cervical intervertebral separation. Spine. 1992;17(2):136-8.

9. Marčić A. Križobolja. Jastrebarsko: Naklada Slap; 2009. 413-420.

10. Johnson EK, Chiarello CM. The slump test: the effects of head and lower extremity position on knee extension. The Journal of orthopaedic and sports physical therapy. 1997;26(6):310-7.

11. Rubinstein SM, Pool JJ, van Tulder MW, Riphagen II, de Vet HC. A systematic review of the diagnostic accuracy of provocative tests of the neck for diagnosing cervical radiculopathy. European spine journal. 2007;16(3):307-19.

12. Malanga GA, Landes $P$, Nadler SF. Provocative tests in cervical spine examination: historical basis and scientific analyses. Pain Physician. 2003;6(2):199-205.

13. Davis DS, Anderson IB, Carson MG, Elkins CL, Stuckey LB. Upper limb neural tension and seated slump tests: the false positive rate among healthy young adults without cervical or lumbar symptoms. Journal of manual and manipulative therapy. 2008;16(3):136-41.

14. Majlesi J, Togay $\mathrm{H}$, Unalan $\mathrm{H}$, Toprak S. The sensitivity and specificity of the Slump and the Straight Leg Raising tests in patients with lumbar disc herniation. Journal of clinical rheumatology. 2008;14(2):87-91.

15. Wainner RS, Fritz JM, Irrgang JJ, Boninger ML, Delitto A, Allison S. Reliability and diagnostic accuracy of the clinical examination and patient self-report measures for cervical radiculopathy. Spine. 2003; 28(1):52-62.

16. Shah KC, Rajshekhar V. Reliability of diagnosis of soft cervical disc prolapse using Spurling's test. British journal of neurosurgery. 2004;18(5):480-3.

17. Graberski M, Bobinac-Georgievski A, Matasović T, Aljinović I, Gabrić S. Electrokinesiological Technique in the Assessment of Spinal Function. Collegium antropologicum. 1993;17(2):339-344. 
18. Tong HC, Haig AJ, Yamakawa K. The Spurling test and cervical radiculopathy. Spine. 2002;27(2):156-9.

19. Miller KJ. The slump test: clinical applications and interpretations. Chiropractic Technique. 1999;11(4):157-163.

20. Eyerman EL. Simple Pelvic Traction Gives Inconsistent Relief to Herniated Lumbar Disc Suffers. Journal of Neuroimaging. 1998; Rad je prikazan na American Society of Neuroimaging, Orlando, Florida 2-26-98.

21. Konstantinou K, Foster N, Rushton A, Baxter D. The use and reported effects of mobilization with movement techniques in low back pain management; a cross-sectional descriptive survey of physiotherapists in Britain. Manual therapy. 2002;7(4):206-14.

22. Ojoawo AO, Olabode A, Esan O, Badru A, Odejide S, Arilewola B. Therapeutic Efficacy of Cervical Traction in the Management of Cervical Radiculopathy. Rwanda Journal of Health Sciences. 2013;2(2):25-29.

23. Shealy CN. Cervical decompression treatment. Practical pain management. 2007;4:14-16.

24. Sang-Yeol M, Hyeong-Dong K. The Effect of Motorized Spinal Decompression Delivered via SpineMED Combined with Physical Therapy Modalities for Patients with Cervical Radiculopathy. Journal of physical therapy science. 2010;22(4):429-435.

25. Fritz JM, Thackeray A, Brennan GP, Childs JD. Exercise only, exercise with mechanical traction, or exercise with over-door traction for patients with cervical radiculopathy, with or without consideration of status on a previously described subgrouping rule: a randomized clinical trial. The Journal of orthopaedic and sports physical therapy. 2014;44(2):45-57.

26. Krapac L. Problemi reumatskih tegoba i bolesti u žena s obzirom na način i uvjete rada. Migracijske teme. 1990;6(Suppl. 4):79-85.

27. Medina F, Bossi AM. i sur. Medicinski leksikon. Naklada Mosta; 2004. 388-392.

28. Silman AJ, Hochberg MC. Epidemiology of the rheumatic diseases. Oxford: Oxford University Press; 1993.

29. Ghasemi M, Golabchi K, Mousavi SA, Asadi B, Rezvani M, Shaygannejad V, Salari M. The value of provocative tests in diagnosis of cervical radiculopathy. Journal of research in medical sciences. 2013;18(Suppl. 1):S35-8.

30. Shabat S, Leitner Y, David R, Folman Y. The correlation between Spurling test and imaging studies in detecting cervical radiculopathy. Journal of neuroimaging. 2012;22(4):375-8.

31. Wainner RS, Gill H. Diagnosis and nonoperative management of cervical radiculopathy. The Journal of orthopaedic and sports physical therapy. 2000;30(12):728-44. 


\section{EFFECTIVENESS OF THE SPINAL DECOMPRESSION THERAPY IN PATIENTS WITH CERVICOBRACHIAL SYNDROME}

1 Lidija Pavlović

2 Dalibor Kiseljak

2 Olivera Petrak

1 Lumbalis Centre, Sveti Martin na Muri

2 University of Applied Health Sciences, Zagreb

\section{Abstract}

Cervicobrachial syndrome greatly impairs the performance of the activities of daily living and professional activities, and it is the subject of many studies. Compression of neurological structures due to the herniation of the intervertebral disc with sensomotor deficit is an indication for surgical treatment. In recent years, the interest in traction (decompression) as a treatment modality has been increasing and many new methods based on the neurophysiological and biochemical principles have been developed. Therefore, traction has been increasingly applied in the treatment of various conditions. Spinal decompression therapy presents a non-invasive approach to the cervicobrachial syndrome treatment.

The objective of this study is to verify the success of spinal decompression therapy measured as an outcome of the specific neurodynamic tests in patients with cervicobrachial syndrome, and to determine the relationship between socio-demographic factors and the success of the spinal decompression therapy in cervicobrachial syndrome.
The sample was comprised of 50 participants (54\% women), with cervicobrachial syndrome, aged 28-68 years (mean age of 50). Acute symptoms were present in $62 \%$ of the patients and chronic symptoms in $38 \%$. The frequency of the therapy sessions ranged from 3 to 8 , with the dominant value of 4 . For the purposes of the research three specific tests were used: Slump Test, Spurling's test and cervical distraction test.

After the finalization of the spinal decompression therapy of the patients with the cervicobrachial syndrome there are significant differences in the results of the Slump test, Spurling's test and cervical distraction test, compared to the pre-treatment status: after the treatment there are significantly more patients who successfully pass these tests. From the analyzed socio-demographic features, the age of the participants seems to be significant: participants who successfully solve the Slump and Spurling's post-treatment tests are significantly younger than the unsuccessful participants. After the therapy, chronic patients, in comparison to the acute patients, have significantly lower performance in all three tests. These two groups also differ in age chronic patients are significantly older, while no significant differences are found in the number of the therapy sessions. In the regression analysis, the duration of the problem has proven to be a significant predictor, as opposed to age which proved to be insignificant. Gender, weight and the number of therapy sessions are not related to the assessment outcomes.

Keywords: cervicobrachial syndrome, spinal decompression therapy, traction, neurodynamic assessment 